
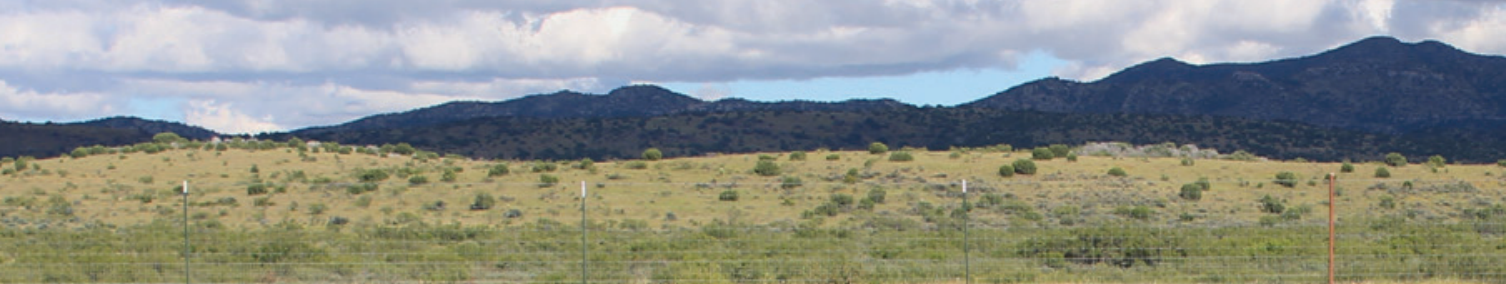

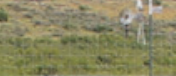




\title{
SANTIAGO GERMPLASM SILVER BLUESTEM: A SELECTED CLASS OF NATURAL GERMPLASM
}

\author{
Colin Shackelford, Jameson S Crumpler, Forrest S Smith, Keith A Pawelek, John Reilley, Shelly D Maher, \\ and Brandon Carr
}

ABSTRACT

Santiago Germplasm silver bluestem (Bothriochloa laguroides (DC.) Herter ssp. torreyana (Steud.) Allred \& Gould [Poaceae]) was cooperatively released in 2017 as a Texas Selected Native Plant Germplasm. This germplasm is a blend of 3 native populations of $B$. laguroides selected through evaluation of 31 populations of silver bluestem and 21 populations of cane bluestem (Bothriochloa barbinodis (Lag.) Herter) originating from 2 ecoregions in West Texas: Southern Desertic Basins, Plains and Mountains and Western Edwards Plateau. To meet management needs within the area of intended use (West Texas), the accessions included in the release were selected based on proof of acceptable seed fill and germination, and on observations of greater survival, plant vigor, seed production, and biomass production in comparison with other native accessions, other silver bluestem germplasm releases, and a commercially available selection. Ocular estimated variables for selected accessions were 43 to $66 \%$ higher than non-selected accessions when averaged across 2 sites and $2 \mathrm{y}$. Plant height for selected accessions was $14 \%$ taller and canopy cover was $7 \%$ higher than non-selected accessions. Seed germination was $48 \%$ greater for the selected accessions. Release of Santiago Germplasm silver bluestem will provide an ecotypic seed source of a widespread native grass for use in West Texas. It provides the first ecotypic seed source of B. laguroides for use in the Western Edwards Plateau; the Southern Desertic Basins, Plains and Mountains; the Southern High Plains; and the Central Rolling Red Prairies ecoregions of Texas.

Shackelford C, Crumpler JS, Smith FS, Pawelek KA, Reilley J, Maher SD, Carr B. 2021. Notice of release of Santiago Germplasm silver bluestem: a selected class of natural germplasm. Native Plants Journal 22(2):146-155.

\section{KEY WORDS}

Bothriochloa laguroides, West Texas, silver bluestem, restoration, Poaceae

\section{NOMENCLATURE}

Plants: USDA NRCS (2020)

Major Land Resource Areas (MLRA): USDA NRCS (2006)

Photos by Colin Shackelford

This open access article is distributed under the terms of the CC-BY-NC-ND license (http://creative commons.org/licenses/by-nc-nd/4.0) and is freely available online at: http://npj.uwpress.org. 
Species: Bothriochloa laguroides (DC.) Herter ssp. torreyana (Steud.) Allred \& Gould (Poaceae)

Common name: Santiago Germplasm silver bluestem

Accession number: 9112293

Collaborators: Texas Native Seeds Program, Caesar Kleberg Wildlife Research Institute, Texas A\&M University-Kingsville; Borderlands Research Institute, Sul Ross State University, Alpine, Texas; USDA NRCS E "Kika" de la Garza Plant Materials Center, Kingsville, Texas; USDA NRCS James E "Bud" Smith Plant Materials Center, Knox City, Texas

ilver bluestem (Bothriochloa laguroides (DC.) Herter ssp. torreyana (Steud.) Allred \& Gould [Poaceae]) is a common, native warm-season grass found across the southern half of the US. Distribution extends primarily north to Nebraska, east to Georgia, west to Arizona, and south across northeastern Mexico (Powell 1994). Silver bluestem occurs in every county in the Trans Pecos of Texas (Powell 1994) and is one of the most widely distributed grasses in Texas, occurring in nearly every county (Turner and others 2003).

\section{JUSTIFICATION}

Throughout many temperate and semi-arid regions of Texas, silver bluestem has the potential for widespread use in restoration and reclamation seedings. Two releases of the similar species Bothriochloa barbinodis (Lag.) Herter (cane bluestem) have been developed for regions west of Texas: Saltillo Origin Germplasm cane bluestem developed in 2001 by the USDA Natural Resources Conservation Service (NRCS) Tucson Plant Materials Center (PMC); and Grant Germplasm cane bluestem developed in 2001 by the NRCS Los Lunas PMC in New Mexico. However, no regionally adapted or ecotypic seed source of silver bluestem has been developed for use in Texas. As a result, the West Texas Native Seeds Project (WTN) of the Texas Native Seeds Program (TNS), a collaborative effort of the Caesar Kleberg Wildlife Research Institute at Texas A\&M Kingsville, the Borderlands Research Institute at Sul Ross State University, the USDA NRCS E "Kika" de la Garza PMC, and the USDA NRCS James E "Bud" Smith PMC, began work to collect, evaluate, and develop a seed release of a blend of local populations for use in West Texas. We based our approach on the theoretical and scientific basis that a locally adapted and regionally sourced seed selection would closely mirror the natural makeup of silver bluestem populations in the region and

\section{COLLECTION SITE INFORMATION}

We obtained seed collections from native populations of silver bluestem and cane bluestem at 52 field locations in West Texas from 2011-2012 (Table 1), and after evaluation, we selected 3 populations for Santiago Germplasm silver bluestem. These 3 collections originated on road rights-of-way in Kinney, Reeves, and Brewster Counties (Figure 1). The selected accessions include Accession 9109995 collected from a Uvalde silty clay loam soil in Kinney County, Accession 9111584 collected from a Reakor loam soil in Reeves County, and Accession 9111617 collected from a Martillo-Butcherknife clay loam soil in Brewster County (USDA NRCS 2019).

\section{DESCRIIPTION}

Santiago Germplasm silver bluestem is similar in general morphology to wild populations. Silver bluestem is a native, cespitose, perennial bunchgrass. Culms are erect from a geniculate base and can grow to $1.5 \mathrm{~m}(5 \mathrm{ft})$ tall and branch above the base at maturity. Leaves are basal and cauline. Sheaths are terete and glaucose with ciliate membrane ligules up to $3.5 \mathrm{~mm}$ ( $0.15 \mathrm{in})$ long. Culm nodes are glabrous or short pubescent. Leaf blades are flat or folded and can grow to $25 \mathrm{~cm}$ (10 in) in length and to $18 \mathrm{~mm}$ (0.7 in) in width. Panicles can be up to $20 \mathrm{~cm}$ ( $8 \mathrm{in}$ ) long, are silvery-white in color, and are contracted and oblong with a central axis to $15 \mathrm{~cm}$ (6 in) in length. Panicle rames number 12 or more, are less than $7 \mathrm{~cm}$ (3 in) long, with some rebranching. Sessile spikelets are less than $4.4 \mathrm{~mm}$ (0.2 in) long. The length of first glumes is 2.5 to $4.5 \mathrm{~mm}(0.1-0.2 \mathrm{in})$, and it does not have a glandular pit; the length of second glumes is similar. Upper floret lemmas are geniculate and twisted below with awns up to $15 \mathrm{~mm}$ (0.6 in) long. Pedicellate spikelets are up to $3 \mathrm{~mm}$ ( $0.1 \mathrm{in})$ long, shorter than sessile spikelets, and awnless. Caryopses are 1.6 to $2.5 \mathrm{~mm}$ (0.06-0.1 in) long, lanceolate, and amber in color. 
Bothriochloa species collections from Texas evaluated in the development of Santiago Germplasm.

\begin{tabular}{|c|c|c|c|c|}
\hline Accession & Genus Bothriochloa, species & County & Location & Soil texture \\
\hline 9089003 & laguroides & Uvalde & Highway 90 just east of Kinney county line & Loam \\
\hline 9090632 & laguroides & Val Verde & Highway 163 north of Comstock & Loam \\
\hline 9109978 & laguroides & Terrell & Longfellow Ranch HQ & Gravelly loam \\
\hline 9109983 & barbinodis & Terrell & Highway 349 south of Sheffield & Gravelly loam \\
\hline 9109986 & barbinodis & Val Verde & Highway 90 west of Del Rio & Silty clay \\
\hline 9109991 & laguroides & Brewster & Highway 67 near Hovey & Loam \\
\hline 9109992 & laguroides & Pecos & I-10 west of Sheffield & Gravelly loam \\
\hline 9109993 & barbinodis & Terrell & Longfellow Ranch NE Reiniger Pasture & Silty clay loam \\
\hline 9109994 & barbinodis & Uvalde & Highway 55 and 334 at Laguna & Silty clay loam \\
\hline 9109995 & laguroides & Kinney & Highway 334 & Silty clay loam \\
\hline 9110016 & laguroides & Brewster & Highway 90 b/t Alpine and Marathon & Silt loam \\
\hline 9110045 & barbinodis & Jeff Davis & TNC Davis Mountains Preserve & Very gravelly sandy loam \\
\hline 9110050 & barbinodis & Brewster & FM 1703 west of Alpine & Very gravelly loam \\
\hline 9110051 & laguroides & Terrell & Hwy 90 between Sanderson and Dryden & Gravelly loam \\
\hline 9110052 & laguroides & Uvalde & Hwy 127 and 83, Concan & Clay \\
\hline 9110053 & laguroides & Brewster & Hwy 90 west of Sanderson & Loam \\
\hline 9111577 & barbinodis & Jeff Davis & Hwy 17 between Ft Davis and Marfa & Loam \\
\hline 9111584 & laguroides & Reeves & I-10 east of Balmorhea, east of Hwy 2448 & Loam \\
\hline 9111586 & laguroides & Pecos & Hwy 1776 and Hwy 1450 & Gravelly loam \\
\hline 9111590 & laguroides & Jeff Davis & Hwy 90 east of Valentine & Clay loam \\
\hline 9111617 & laguroides & Brewster & Hwy 118 south of Alpine & Clay loam \\
\hline 9111619 & barbinodis & Brewster & Hwy 118 north of Study Butte & Very gravelly sandy loam \\
\hline 9111621 & laguroides & Brewster & Hwy 118 north of Study Butte & Very gravelly sandy loam \\
\hline 9111622 & barbinodis & Brewster & Hwy 118 south of Alpine & Gravelly loam \\
\hline 9111626 & laguroides & Presidio & Hwy 169 south of Marfa & Silt clay loam \\
\hline 9111640 & laguroides & Dawson & Hwy 180 west of Lamesa & Fine sandy loam \\
\hline 9111641 & laguroides & Gaines & Hwy 180 west of Lamesa & Loamy fine sand \\
\hline 9111652 & barbinodis & Brewster & Mount Ord Ranch, Hwy 118 south of Alpine & Extremely gravelly loam \\
\hline 9111671 & laguroides & Ector & K-Bar Ranch, south of Odessa & Very gravelly sandy loam \\
\hline 9111674 & laguroides & Crane & K-Bar Ranch, south of Odessa & Loam \\
\hline 9111677 & laguroides & Upton & Hwy 1492 , south of Midland & Very gravelly sandy loam \\
\hline 9111681 & laguroides & Martin & I-20 west of Big Spring & Loam \\
\hline 9111682 & laguroides & Ward & Hwy 1776 north of the Pecos River & Very gravelly loam \\
\hline 9111700 & laguroides & Culberson & County Rd 114, E-SE of Delaware Mtns & Loam \\
\hline 9111926 & barbinodis & Coke & Butterfield Ranch, 8 mi S of Robert Lee & Clay loam \\
\hline 9111927 & laguroides & Coke & FM 208 south of Robert Lee & Clay loam \\
\hline 9111928 & barbinodis & Uvalde & Highway 55 north of Uvalde & Silt loam \\
\hline 9111929 & barbinodis & Upton & Highway 349 south of Highway 67 & Loam \\
\hline
\end{tabular}




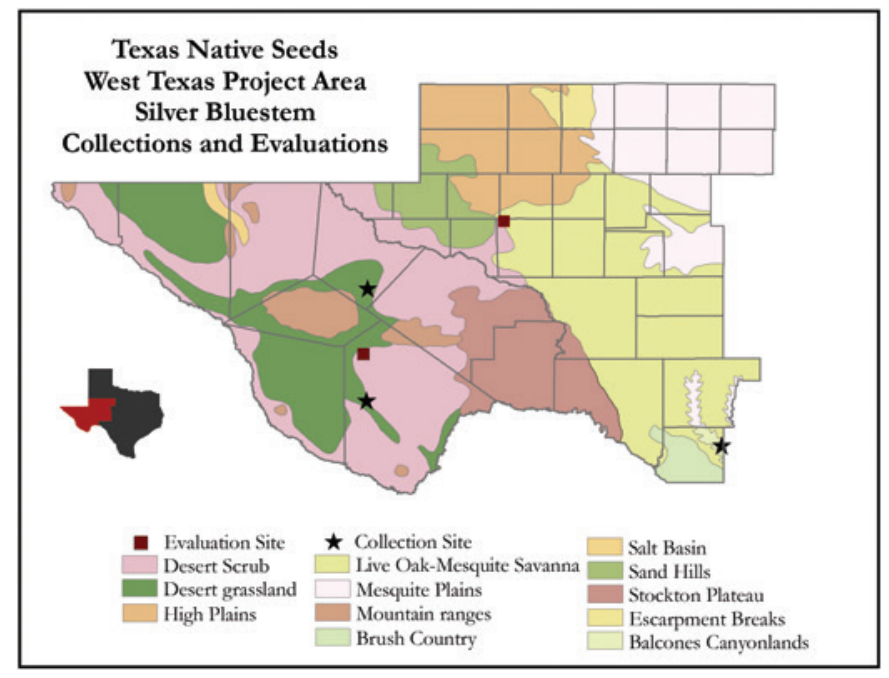

Figure 1. Collection and evaluation sites used in development of Santiago Germplasm silver bluestem (Bothriochloa laguroides (DC.) Herter ssp. torreyana (Steud.) Allred \& Gould [Poaceae]).

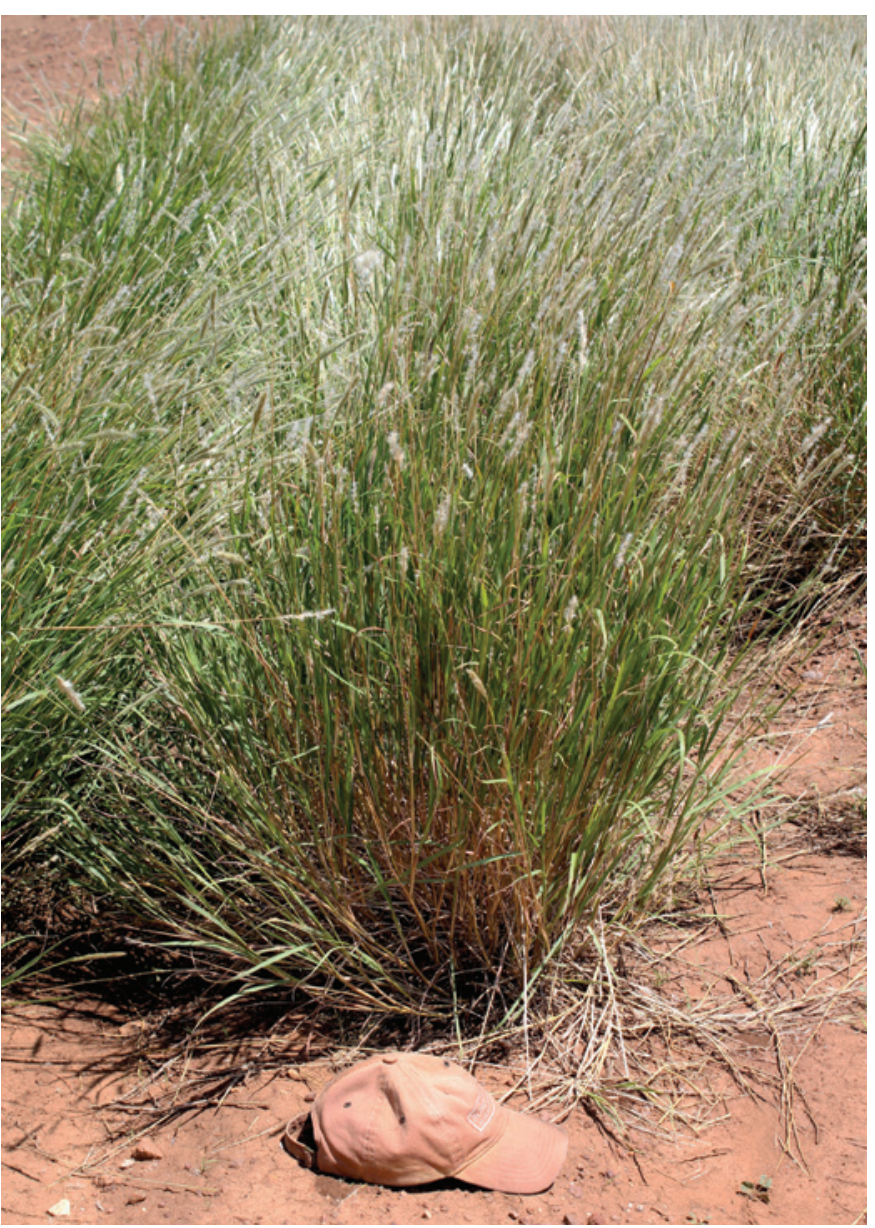

Representative plants of Santiago Germplasm silver bluestem.

Plants produce seed mostly from May through November (Stubbendieck and others 2017). Silver bluestem has an average of 228,606 seeds/ $\mathrm{kg}$ (503,991 seeds/lb). Percent pure live seed

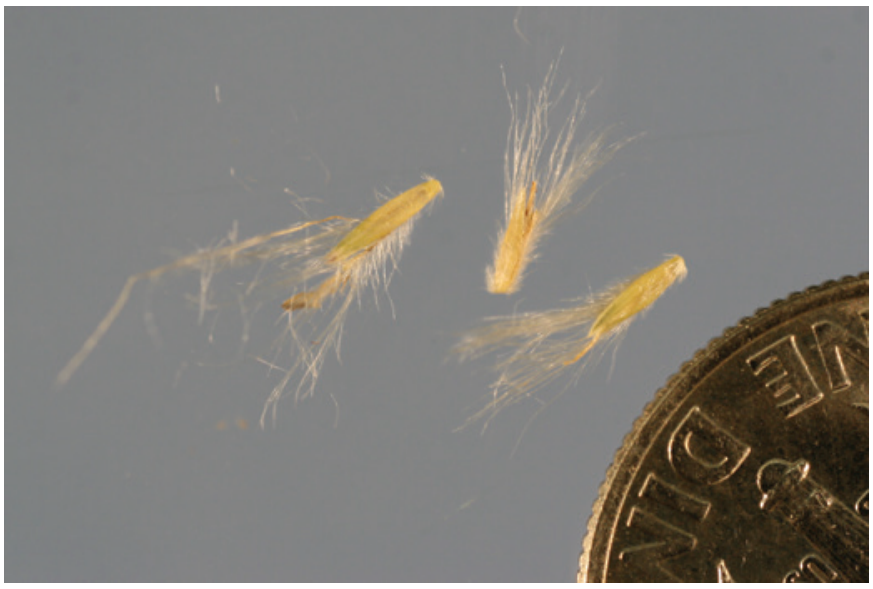

Cleaned seed of Santiago Germplasm silver bluestem (size reference = a US dime).

ranged from 24 to $40 \%$ between accessions. The recommended pure stand seeding rate is 1 to $2 \mathrm{lb}$ pure live seed per acre. Seed yields in commercial production fields have averaged $69.5 \mathrm{~kg}$ per ha (62 bulk lb/ac) per year. Producers can expect 3 to 5 harvests per year depending on production location, growing conditions, and year.

Chromosome number reported for silver bluestem is $2 \mathrm{n}=60$. Ploidy analysis by the National Forest Genetic Electrophoresis Laboratory of each accession making up Santiago Germplasm confirmed Bothriochloa ploidy level first described by Gould (1975).

Silver bluestem is most common in moderately drained soils of prairies, pastures, woodlands, river bottoms, waste ground, and roadsides. It is a hardy perennial and is easily reestablished after droughts and overgrazing (Powell 1994). Forage value is good to fair for all classes of livestock and fair for big game (Powell 1994; Shaw 2012; Stubbendieck and others 2017). Silver bluestem naturally occurs in every county in the Trans Pecos of Texas (Powell 1994), and it is one of the most widely distributed grasses in Texas, occurring in nearly every county (Turner and others 2003)

\section{METHOD OF SELECTION}

As part of an effort to collect, evaluate, and release germplasms of a variety of native plants for West Texas, personnel from the West Texas Native Seeds Project of the Texas Native Seeds Program obtained seed collections of silver bluestem and cane bluestem from 52 field locations in West Texas from 20112012. These Bothriochloa species were selected for evaluation for use in revegetation plantings on rangelands and highway rights-of-way, and for use in upland wildlife habitat restoration plantings. A combined evaluation of both species was chosen because they have considerable overlap in distribution in West Texas and can often be found growing in mixed stands (Powell 1994). 


\section{Initial Evaluation}

In March 2014, 52 accessions of silver bluestem and cane bluestem were seeded in greenhouse flats to produce plants for evaluation. Of 52 accessions, 50 germinated, and in May 2014 plants from these 50 accessions were installed in a randomized, complete block design, common-garden study with 2 replications made up of 10 plants of each accession at the Sierra la Rana evaluation site in Alpine, Texas (see Figure 1). During the first month of establishment, plants were irrigated as needed over a 1-mo period until established. They were then evaluated monthly throughout the growing season in 2014 under natural precipitation conditions. Data were collected on traits important for commercial seed production and ecological function. We estimated quality (1 to 10; best to worst) for plant vigor, foliage density, uniformity of the accession as a whole, forage (biomass) production, and seed production. We directly measured survival (expressed as a percentage of number of plants present/number of plants initially planted), plant height, and plant canopy cover. Mean performance in each category by year was used for selection of superior accessions. Seed was collected from each accession when ripe throughout the growing season. Three samples of 100 seeds each from the composited seed of each accession were tested for germination annually.

\section{Advanced Evaluation}

Following the initial evaluation during the summer of 2014, the 10 best-performing accessions (these showed greater than mean performance in the largest number of evaluation categories; Table 2) were selected for advanced evaluation plantings at the Sierra la Rana plant evaluation site in Alpine and the Railway Ranch plant evaluation site south of Odessa, Texas (see Figure 1)

In addition to the 10 highest-performing accessions, releases of Grant Germplasm cane bluestem developed by the Los Lunas PMC, Starr Germplasm longspike silver bluestem under development by the E "Kika" de la Garza PMC, and a commercially available selection of silver bluestem produced by Turner Seed Company in Breckenridge, Texas, were included in the evaluation. Transplants were grown from the original seed collections, breeder seed obtained from the PMC's for their releases, and commercial seed from the Turner Seed Company.

At the Alpine site, each accession, release, and commercial selection was planted in paired 10-plant replications. The intent of this design was to better evaluate uniformity of development, seed yields, seed quality, and seed harvestability. At the Odessa site, a randomized, complete block design of 2, 10-plant replications of each accession and existing releases was planted. Accession 9090632 had poor greenhouse emergence; the limited plants available were evaluated only at Odessa because that site is more representative of where the accession originated.
TABLE 2

Accessions selected for advanced evaluation and rationale for selection.

\begin{tabular}{|c|c|c|}
\hline Accession & Selection criteria & Rank \\
\hline 9090632 & $\begin{array}{l}\text { - Vigor } \\
\text { - Uniformity }\end{array}$ & $\begin{array}{l}\text { - 9th } \\
\text { - 6th }\end{array}$ \\
\hline 9109994 & $\begin{array}{l}\text { - Vigor } \\
\text { - Foliage density } \\
\text { - Seed production } \\
\text { - Forage production }\end{array}$ & $\begin{array}{l}\text { - 8th } \\
\text { - 7th } \\
\text { - 4th (tie) } \\
\text { - 6th (tie) }\end{array}$ \\
\hline 9109995* & $\begin{array}{l}\text { - Vigor } \\
\text { - Foliage density } \\
\text { - Uniformity } \\
\text { - Seed production } \\
\text { - Forage production }\end{array}$ & $\begin{array}{l}\text { - 5th } \\
\text { - 5th } \\
\text { - 7th } \\
\text { - 4th (tie) } \\
\text { - 4th (tie) }\end{array}$ \\
\hline 9110014 & $\begin{array}{l}\text { - Vigor } \\
\text { - Foliage density } \\
\text { - Uniformity } \\
\text { - Seed production } \\
\text { - Forage production }\end{array}$ & $\begin{array}{l}\text { - 2nd } \\
\text { - 2nd } \\
\text { - 3rd (tie) } \\
\text { - 2nd } \\
\text { - 3rd }\end{array}$ \\
\hline 9110045 & $\begin{array}{l}\text { - Vigor } \\
\text { - Uniformity } \\
\text { - Seed production } \\
\text { - Forage production }\end{array}$ & $\begin{array}{l}\text { - 10th (tie) } \\
\text { - 3rd (tie) } \\
\text { - 10th (tie) } \\
\text { - 9th (tie) }\end{array}$ \\
\hline 9110050 & $\begin{array}{l}\text { - Uniformity } \\
\text { - Active germination }\end{array}$ & $\begin{array}{l}\text { - 2nd (tie) } \\
\text { - 6th (tie) }\end{array}$ \\
\hline $9111584^{*}$ & $\begin{array}{l}\text { - Vigor } \\
\text { - Foliage density } \\
\text { - Uniformity } \\
\text { - Seed production } \\
\text { - Forage production } \\
\text { - Active germination }\end{array}$ & $\begin{array}{l}\text { - } 6 \text { th (tie) } \\
\text { - } 7 \text { th (tie) } \\
\text { - 3rd (tie) } \\
\text { - } 5 \text { th } \\
\text { - } 6 \text { th } \\
\text { - } 1 \text { st }\end{array}$ \\
\hline $9111617^{*}$ & $\begin{array}{l}\text { - Vigor } \\
\text { - Foliage density } \\
\text { - Uniformity } \\
\text { - Seed production } \\
\text { - Forage production }\end{array}$ & $\begin{array}{l}\text { - } 1 s t \\
\text { - } 1 s t \\
\text { - } 1 s t \\
\text { - } 1 s t \\
\text { - } 1 s t\end{array}$ \\
\hline 9111621 & $\begin{array}{l}\text { - Vigor } \\
\text { - Foliage density } \\
\text { - Uniformity } \\
\text { - Seed production } \\
\text { - Forage production } \\
\text { - Active germination }\end{array}$ & $\begin{array}{l}\text { - } 7 \text { th } \\
\text { - } 7 \text { th } \\
\text { - } 9 \text { th (tie) } \\
\text { - } \text { 6th (tie) } \\
\text { - 5th (tie) } \\
\text { - 9th }\end{array}$ \\
\hline 9111622 & $\begin{array}{l}\text { - Vigor } \\
\text { - Foliage density } \\
\text { - Uniformity } \\
\text { - Forage production }\end{array}$ & $\begin{array}{l}\text { - 9th (tie) } \\
\text { - 9th (tie) } \\
\text { - 5th (tie) } \\
\text { - 7th }\end{array}$ \\
\hline
\end{tabular}

Notes: Asterisk $\left({ }^{*}\right)$ denotes accessions included in Santiago Germplasm silver bluestem.

Plantings were irrigated during the first month until plants were well established, and then plants had natural precipitation conditions. We made quality estimates ( 1 to 10 ; best to worst) for plant vigor, foliage density, uniformity of the accession as a whole, forage (biomass) production, and seed production. We directly measured survival (expressed as a percentage of number of plants present/number of plants initially planted), 
plant height, and plant canopy cover. Data were collected once a month for 1 growing season at each evaluation site. A composite sample of all annual seed production for each accession was tested for germination.

\section{Selection}

We selected 3 accessions to be released as Santiago Germplasm silver bluestem based on 1) data from an initial evaluation of 50 accessions on 1 site (Table 2);2) advanced evaluation on 2 sites of the 10 best accessions from the initial evaluation (Tables 4 and 5); 3) seed quality and germination data (Tables 4 and 5); and 4) soil texture and ecological site information from the original collection locations (Table 1).

Mean scores for plant performance showed that selected accessions scored better than non-selected accessions (Table 3) as well as the Grant Germplasm cane bluestem, Starr Germplasm longspike silver bluestem, and Turner Seed Company silver bluestem planted as comparison standards. Plant performance scores for selected accessions were 43 to $66 \%$ higher across all ocular estimate variables than were non-selected TABLE 4
TABLE 3

Comparative difference in evaluation scores of selected and nonselected accessions of silver bluestem at the 2 planting sites.

\begin{tabular}{lccc} 
Category & $\begin{array}{c}\text { Selected } \\
\text { accessions }\end{array}$ & $\begin{array}{c}\text { Non-Selected } \\
\text { accessions }\end{array}$ & \% Difference \\
\hline Survival (\%) & 99.5 & 94.0 & 5.9 \\
Plant vigor* & 2.7 & 4.5 & 66.7 \\
Foliage density* & 2.7 & 4.5 & 66.7 \\
Uniformity* & 3.0 & 4.3 & 43.3 \\
Seed production* & 3.5 & 5.1 & 45.7 \\
Forage production* & 2.9 & 4.8 & 65.5 \\
Plant height (cm) & 85.3 & 74.8 & 14.0 \\
Plant cover (\%) & 97.0 & 90.5 & 7.2 \\
Active seed germ (\%) & 41.2 & 27.8 & 48.0 \\
\hline
\end{tabular}

${ }^{*}$ Ocular estimates with 1 being the best and 10 being the poorest.

accessions when averaged across sites and years. Plant height for selected accessions was on average 14\% higher and canopy cover was $76 \%$ higher than non-selected accessions. Percent

Mean values for all evaluation criteria and active germination rates for non-selected accessions, selected accessions, and existing commercial releases at the Alpine evaluation site.

\begin{tabular}{|c|c|c|c|c|c|c|c|c|c|c|}
\hline \multirow[b]{2}{*}{ Accession } & \multirow[b]{2}{*}{ \# Plants } & \multirow[b]{2}{*}{ Vigor* $^{*}$} & \multirow[b]{2}{*}{ Foliage density* } & \multirow[b]{2}{*}{ Uniformity* } & \multirow[b]{2}{*}{ Seed production* } & \multirow[b]{2}{*}{ Forage production* } & \multirow[b]{2}{*}{ Height } & \multirow[b]{2}{*}{ Cover } & \multicolumn{2}{|c|}{$\begin{array}{c}\text { Germination } \\
(\%)\end{array}$} \\
\hline & & & & & & & & & 2014 & 2015 \\
\hline \multicolumn{11}{|c|}{ Accessions not selected - Alpine data } \\
\hline 9109994 & 9.5 & 3.3 & 3.3 & 3.5 & 4.3 & 3.8 & 69.3 & 91.0 & 36.7 & 11.3 \\
\hline 9110014 & 10.0 & 4.5 & 4.5 & 4.0 & 5.3 & 4.8 & 66.5 & 78.3 & 16.3 & 19.0 \\
\hline 9110045 & 9.0 & 5.3 & 5.3 & 4.0 & 5.8 & 5.8 & 60.3 & 81.0 & 31.7 & 25.0 \\
\hline 9111621 & 10.0 & 3.5 & 3.3 & 4.5 & 5.8 & 4.0 & 66.0 & 87.3 & 42.7 & 14.0 \\
\hline 9111622 & 10.0 & 5.8 & 5.5 & 5.8 & 6.8 & 6.3 & 58.0 & 79.0 & 37.0 & 25.7 \\
\hline Mean & 9.8 & 4.5 & 4.4 & 4.4 & 5.5 & 4.9 & 65.6 & 85.0 & 34.9 & 19.7 \\
\hline \multicolumn{11}{|c|}{ Selected accessions - Alpine data } \\
\hline Mean & 9.9 & 2.5 & 2.5 & 2.4 & 3.8 & 2.8 & 76.6 & 96.2 & 44.0 & 25.0 \\
\hline \multicolumn{11}{|c|}{ Existing releases - Alpine data } \\
\hline & & & & & & & & & \multicolumn{2}{|c|}{$\begin{array}{c}\text { Germination } \\
(\%)\end{array}$} \\
\hline Release & \# Plants & Vigor* $^{*}$ & Foliage density* & Uniformity* & Seed production $^{*}$ & Forage production* & Height & Cover & 2014 & 2015 \\
\hline Grant & 9.5 & 4.8 & 5.0 & 4.5 & 5.8 & 5.0 & 78.8 & 93.3 & N/A & 19.7 \\
\hline Starr & 9.0 & 2.5 & 2.5 & 4.0 & 3.8 & 3.0 & 80.8 & 91.5 & $\mathrm{~N} / \mathrm{A}$ & 33.7 \\
\hline Turner & 10.0 & 4.5 & 4.5 & 2.5 & 3.5 & 4.0 & 86.5 & 99.0 & $\mathrm{~N} / \mathrm{A}$ & 21.3 \\
\hline Mean & 9.5 & 3.9 & 4.0 & 3.7 & 4.3 & 4.0 & 82.0 & 94.6 & & 24.9 \\
\hline
\end{tabular}

* Ocular estimates with 1 being the best and 10 the poorest. All other variables are direct measurements. 
active germination was $48 \%$ higher for selected accessions as well (Table 3).

Accession 9109995 was selected as the easternmost highperforming accession from a clay loam ecological site from MRLA 81A. It had the highest score for vigor (a three-way tie with the other 2 accessions of Santiago Germplasm), foliage density, uniformity, seed production, and forage production at the Alpine site. Seed produced at Alpine during both years of evaluation had the third highest germination rate and the least variation (Table 4). This accession had the second highest score for vigor, foliage density, uniformity, seed production, and forage production at Odessa (Table 5).

Accession 9111584 was selected as the northernmost highperforming accession from a loamy ecological site from MRLA 42. It had the highest score for vigor (a three-way tie with the other 2 accessions of Santiago Germplasm), and the second highest score for foliage density, uniformity, seed production, and forage production at the Alpine site (Table 4). Seed germination was the highest at Alpine (Table 4) and Odessa (Table 5). Accession 9111584 was the fourth highest scoring accession for vigor, foliage density, and uniformity as well as the third highest scoring accession for seed production and forage production at the Odessa site (Table 5).

Accession 9111617 was selected as the southernmost highperforming accession from a clay loam ecological site from MRLA 42. It had the highest score for both vigor (a threeway tie with the other 2 accessions of Santiago Germplasm) and forage production as well as the second highest scores for foliage density and uniformity, and the fourth highest score for seed production at the Alpine site (Table 4). This accession also had the fourth highest score for vigor and forage production and the second best germination rate at the Odessa site (Table 5).

\section{Seed Increase}

Seed increase fields were started using greenhouse-grown plants derived from the original seed collections, which were outplanted on $30 \mathrm{~cm}$ (12 in) centers on $90 \mathrm{~cm}$ (36 in) bedded rows. Each accession was represented by approximately 400 plants. Seed was effectively harvested from these small,

\section{TABLE 5}

Mean values for all evaluation criteria and active germination rates for non-selected accessions, selected accessions, and existing commercial releases at the Odessa evaluation site.

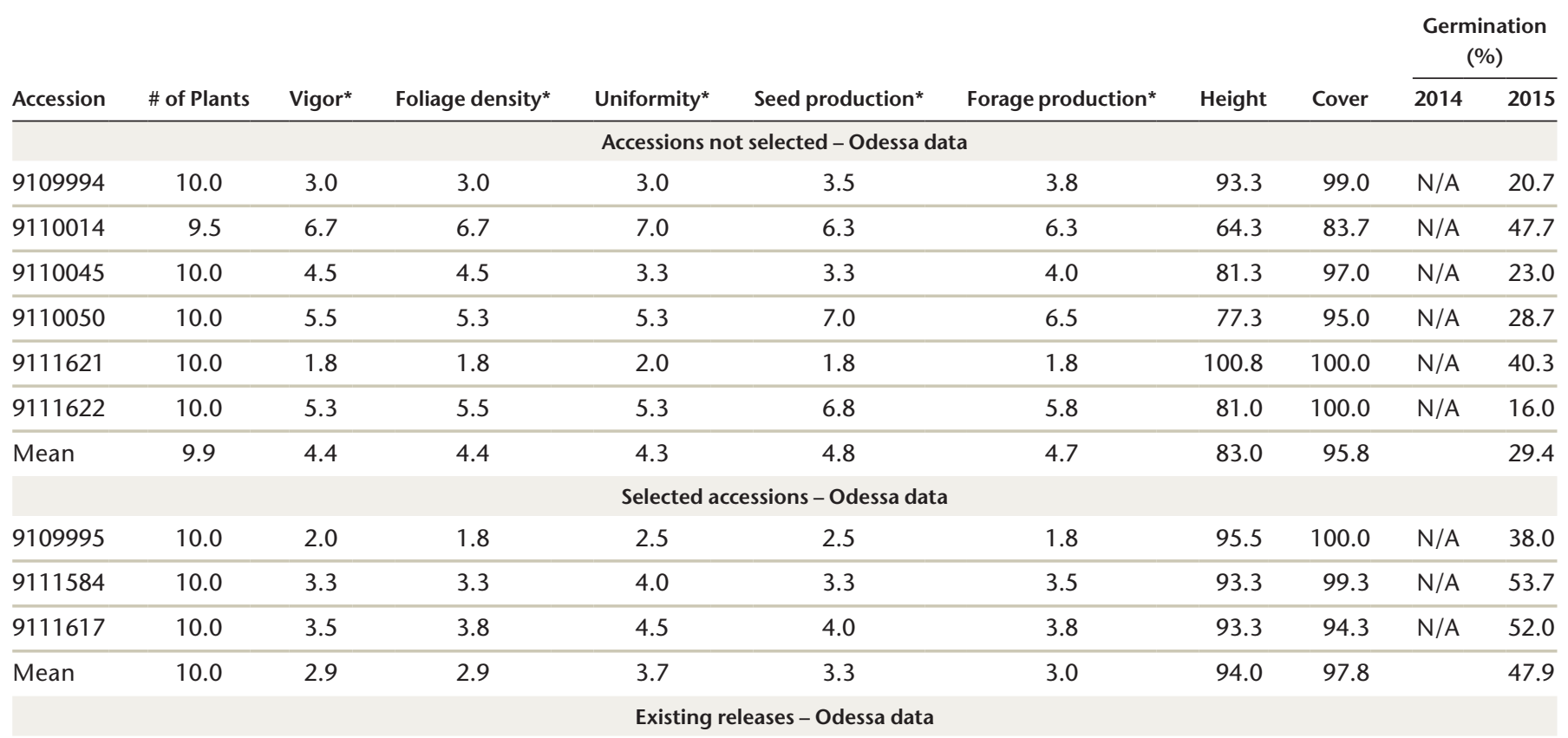

\begin{tabular}{lcccccccccc} 
Release & \# of Plants & Vigor* $^{*}$ & Foliage density* $^{*}$ & Uniformity* $^{*}$ & Seed production* & Forage production* & Height & Cover & 2014 & 2015 \\
\hline Grant & 10.0 & 6.0 & 6.0 & 4.8 & 6.5 & 6.0 & 77.3 & 93.0 & N/A & 29.7 \\
\hline Starr & 10.0 & 4.7 & 5.0 & 5.0 & 4.7 & 5.0 & 85.3 & 91.3 & N/A & 83.3 \\
\hline Turner & 10.0 & 5.0 & 5.0 & 4.3 & 4.8 & 4.5 & 88.5 & 99.8 & N/A & 21.0 \\
\hline Mean & 10.0 & 5.2 & 5.3 & 4.7 & 5.3 & 5.2 & 83.7 & 94.7 & 44.7 \\
\hline
\end{tabular}

* Ocular estimates with 1 being the best and 10 the poorest. All other variables are direct measurements. 
isolated seed increase plots throughout the 2014 and 2015 growing seasons using a Flail-Vac harvester. After air-drying, seed was readily cleaned from the stem and leaf material using a Clipper Seed Cleaner and was then tested for purity and quality. Average PLS from seeds harvested was 35\%; average production was $0.75 \mathrm{~kg}(1.65 \mathrm{lb})$ of PLS per harvest. Estimated annual PLS yield using this production method was $69.5 \mathrm{~kg} / \mathrm{ha}(62 \mathrm{lb} / \mathrm{ac})$.

\section{ECOLOGICAL CONSIDERATIONS}

Silver bluestem is native and adapted to the area of intended use, thus no potential negative impacts of planting the species in this region are anticipated. Based on the natural distribution of this species, plants arising from this germplasm are unlikely to persist or spread beyond locations where the plant naturally occurs.

Silver bluestem reproduces readily from seed. This species does not show any potential for aggressive, rapid spread from seed, unlike exotic species encountered in this region. Aside from tillering via the root crown, silver bluestem does not exhibit any other apparent vegetative reproduction.

The release of Santiago Germplasm silver bluestem will provide a selected seed source of a native plant species for upland wildlife habitat improvement, critical area revegetation, highway and energy rights-of-way plantings, energy exploration and development reclamation, and rangeland plantings for West Texas.

\section{ANTICIPATED CONSERVATION USE}

Santiago Germplasm silver bluestem should be adapted to a broad range of soil textures and ecological sites across West Texas. Best adaptation should be on sites with deeper soils and moderate drainage (Powell 1994). Santiago Germplasm is recommended for inclusion in native seed mixes for upland wildlife plantings, highway rights-of-way revegetation, energy reclamation, and for inclusion in range seeding mixes. It is a fair to good livestock forage and can compete well with exotic grasses such as buffelgrass (Pennisetum ciliare (L.) Link [Poaceae]) (Powell 1994). Silver bluestem provides nesting cover for birds, foraging habitat for raptors, and fawning cover for deer (Hatch and others 1999).

\section{ANTICIPATED AREA OF ADAPTATION}

Based on the distribution of Bothriochloa laguroides, the collection sites of the 3 accessions that make up Santiago Germplasm and the location of the 2 evaluation sites used in development, the best performance of Santiago Germplasm will be predominantly in the western part of the Edwards Plateau (MRLA 81A),
42), the Southern High Plains (MLRA 077C), and the Central Rolling Red Prairies (MLRA 078B) ecoregions. The release may be adapted to adjacent ecoregions, but evaluations have not been conducted outside of the aforementioned regions.

\section{AVAILABILITY OF PLANT MATERIALS}

The parent populations of each component of Santiago Germplasm will be maintained by the West Texas Native Seeds Project. Seed will be made available to growers agreeing to produce seed meeting Texas Department of Agriculture seed certification provisions for Texas Selected Native Plant Germplasm, and pending negotiation of a licensing agreement for production. G0 and G1 production fields will have a 7-y restriction on stand life. Certification through G2 will be allowed, but increase for seed production using G2 seed is prohibited. Rights to production and distribution of seed for commercial purposes will be limited to growers participating in production license agreements with the originating institutions. Seed for scientific research, further selection, or testing purposes can be obtained by e-mailing the corresponding author.

\section{ACKNOWLEDGMENTS}

This article is Caesar Kleberg Wildlife Research Institute Manuscript \#19-112.

\section{REFERENCES}

Gould FW. 1975. The grasses of Texas. College Station (TX): Texas A\&M University Press.

Hatch SL, Schuster JL, Drawe DL. 1999. Grasses of the Texas Gulf prairies and marshes. College Station (TX): Texas A\&M University Press.

Powell AM. 1994. Grasses of the Trans Pecos and adjacent areas. Austin (TX): The University of Texas Press.

Shaw RB. 2012. Guide to Texas grasses. College Station (TX): Texas A\&M University Press.

Stubbendieck JL, Hatch SL, Dunn CD. 2017. Grasses of the Great Plains. College Station (TX): Texas A\&M University Press.

Turner BL, Nichols H, Denny G, Doron O. 2003. Atlas of the vascular plants of Texas, Volume 2. Fort Worth (TX): Botanical Research Institute of Texas.

[USDA NRCS] USDA Natural Resources Conservation Service. 2006. Land resource regions and major land resource areas of the United States, the Caribbean, and the Pacific Basin. Washington (DC): USDA. Agricultural Handbook 296.

[USDA NRCS] USDA Natural Resources Conservation Service. 2019. Web soil survey. URL: http://websoilsurvey.nrcs.usda.gov (accessed 11 May 2019). Lincoln (NE): National Soil Survey Center.

[USDA NRCS] USDA Natural Resources Conservation Service. 2020. The PLANTS database. URL: http://plants.usda.gov (accessed 20 Nov 2020). Greensboro (NC): National Plant Data Team. 


\section{Colin Shackelford}

\section{Assistant Director}

West Texas - Texas Native Seeds (TNS)

Caesar Kleberg Wildlife Research Institute (CKWRI)

Texas A\&M University-Kingsville (TAMUK)

MSC 218, 700 University Blvd

Kingsville, TX 78363

colin.shackelford@tamuk.edu

\section{Jameson S Crumpler}

Research Associate

TNS; Borderlands Research Institute (BRI)

Sul Ross State University (SRSU)

CENT 113, 500 W Avenue H

Alpine, TX 79832

jcru3901@sulross.edu

\section{Forrest S Smith}

Dan L Duncan Endowed Director

TNS, CKWRI, TAMUK

MSC 218, 700 University Blvd

Kingsville, TX 78363

forrest.smith@tamuk.edu

Keith A Pawelek

Associate Director

TNS, CKWRI, TAMUK

MSC 218, 700 University Blvd

Kingsville, TX 78363

keith.pawelek@tamuk.edu

John Reilley

Manager

USDA Natural Resources Conservation Service (NRCS)

E "Kika" de la Garza Plant Materials Center

3409 N FM 1355

Kingsville, TX 78363

John.Reilley@tx.usda.gov

Shelly D Maher

Soil Conservationist

USDA NRCS E "Kika" de la Garza Plant Materials Center 3409 N FM 1355

Kingsville, TX 78363

Shelly.Maher@tx.usda.gov

Brandon Carr

Manager

USDA NRCS, James E "Bud" Smith Plant Materials

Center

3776 FM 1292

Knox City, TX 79529-2514

Brandon.Carr@tx.usda.gov
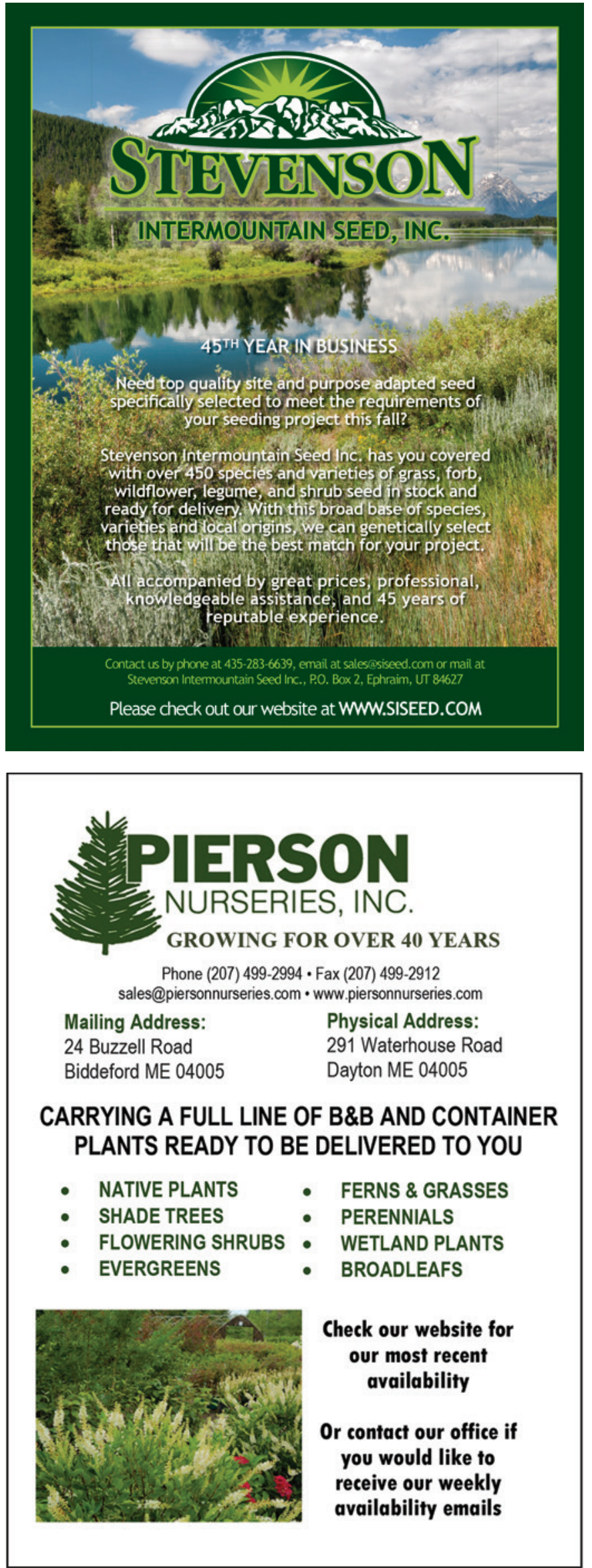


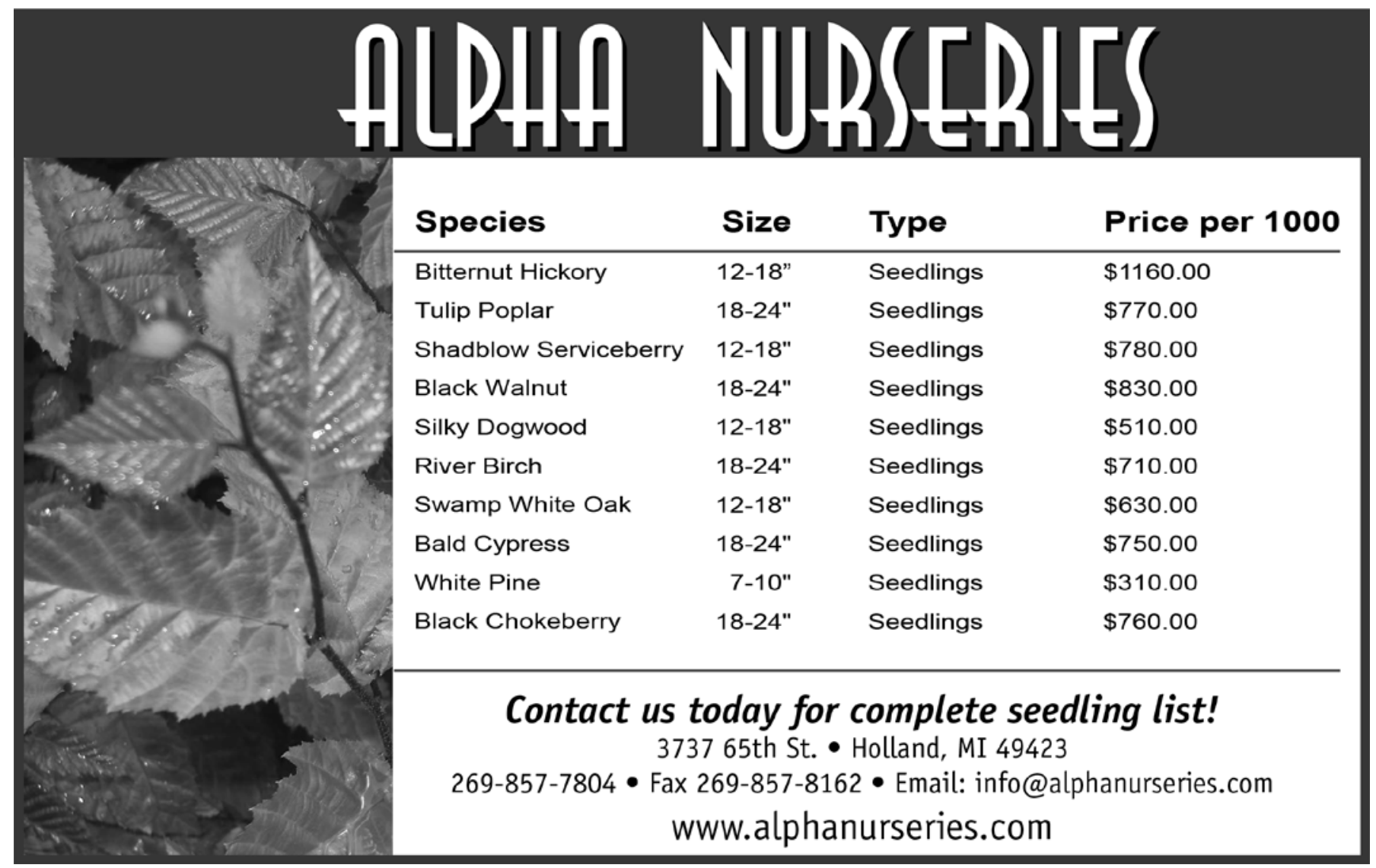

In this era of climate change, conservation alone is not enough. We are the leading international organization working on the science, practice, and policy of ecological restoration.

SER offers peer-reviewed research, regional and world conferences, webinars, practitioner certification, an electronic knowledge hub, in-person and virtual networking, and so much more to every sector of the global restoration community.
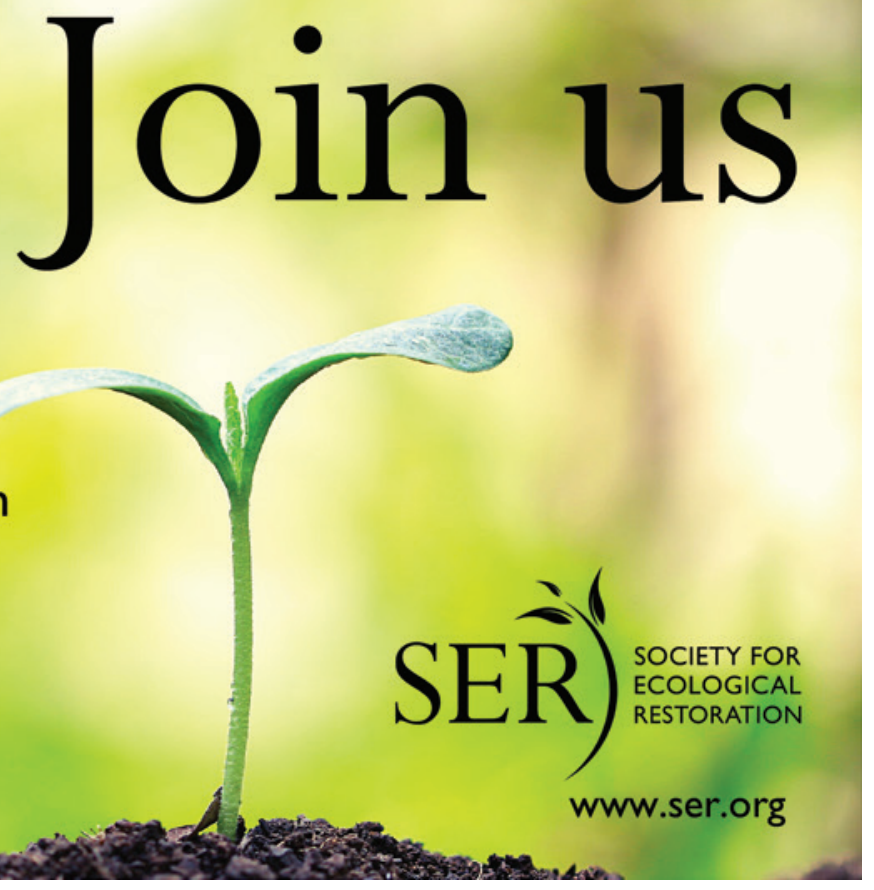